\title{
Irrigation management strategies for reducing verticillium wilt severity in eggplants
}

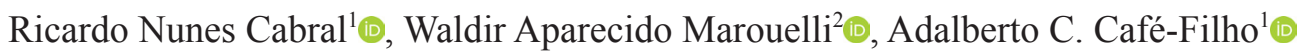

${ }^{1}$ Graduate student (first author) and Professor, Graduate Programme in Plant Pathology, University of Brasília (UnB), Campus Universitário Darcy Ribeiro, Asa Norte, CEP 70.910-900 - Brasília, DF, Brazil; ${ }^{2}$ Embrapa Secretaria Geral, (Embrapa-SGE), Parque Estação Biológica s/n, CEP 70770-901 - Brasília, DF, Brazil. Part of the first author's Master's Dissertation presented to the University of Brasília.

Corresponding author: Adalberto C. Café-Filho (cafefilh@unb.br)

Data de chegada: 10/01/2018. Aceito para publicação em: 28/11/2019.

$10.1590 / 0100-5405 / 190000$

\section{ABSTRACT}

Cabral, R.N.; Marouelli, W.A.; Café-Filho, A.C. Irrigation management strategies for reducing verticillium wilt severity in eggplants. Summa Phytopathologica, v.46, n.1, p.09-13, 2020.

Verticillium wilt in eggplants is a root disease of difficult control. In this study, we report the relationship between soil water availability and the disease intensity in order to identify management strategies that are unfavourable to the pathogen and capable of reducing the disease progression and the damage caused by it. Four irrigation management strategies were compared in soil infested or not infested with Verticillium dahliae, which consisted of: irrigating when the available soil moisture was maintained at $90 \%\left(\mathrm{WA}_{90 \%}\right), 55 \%\left(\mathrm{WA}_{55 \%}\right)$ and $20 \%$ (WA20\%) during the entire growing cycle, and kept at $20 \%$ in the vegetative stage, and at $90 \%$ in the production stage $\left(\mathrm{WA}_{20-90 \%}\right)$. Experimental design was in randomized blocks, including eight treatments in factorial arrangement $(4 \times 2)$ and three replicates. The management strategy $\mathrm{WA}_{20-90 \%}$ led to a significant reduction in the disease severity and in the extent of xylem colonization by the pathogen. The dry mass of plants in infested soil was $12 \%$ lower than that of control treatments and was higher with the irrigation strategy $\mathrm{WA}_{90 \%}$ than with $\mathrm{WA}_{55 \%}$ or $\mathrm{WA}_{20 \%}$. The strategy $\mathrm{WA}_{20-90 \%}$ was efficient in reducing the disease with no significant reduction in dry mass.

Keywords: Solanum melongena, Verticillium dahliae, Soil-borne disease

\section{RESUMO}

Cabral, R.N.; Marouelli, W.A.; Café-Filho, A.C. Manejo da irrigação para redução da murcha de verticílio em berinjela. Summa Phytopathologica, v.46, n.1, p.09-13, 2020.

Murcha de Verticillium em berinjela é uma doença de raiz de difícil controle. Este trabalho relata a relação entre a disponibilidade de água no solo e a intensidade da doença, visando identificar estratégias de manejo que são desfavoráveis ao patógeno e capazes de reduzir o progresso e o dano causados pela doença. Quatro estratégias de manejo de água foram comparadas em solo infestado ou não infestado com Verticillium dahliae, a saber: irrigação mantendo a umidade do solo em $90 \%\left(\mathrm{WA}_{90 \%}\right), 55 \%\left(\mathrm{WA}_{55 \%}\right)$ e $20 \%$ ( $\mathrm{WA}_{20 \%}$ ) durante todo o ciclo da cultura, e $20 \%$ no estágio vegetativo, seguido por irrigação mantendo $90 \%$ no estágio reprodutivo $\left(\mathrm{WA}_{20-90 \%}\right)$. O desenho experimental foi em blocos ao acaso com oito tratamentos em esquema fatorial $(4 \times 2)$ e três repetições. A estratégia $\mathrm{WA}_{20-90 \%}$ levou a uma redução significativa da severidade da doença e na extensão da colonização do xilema pelo patógeno. A massa seca das plantas em solo infestado foi $12 \%$ inferior a das plantas nos tratamentos controle, e foi maior com a estratégia de irrigação $\mathrm{WA}_{90 \%}$ do que em $\mathrm{WA}_{55 \%}$ ou $\mathrm{WA}_{20 \%}$. A estratégia $\mathrm{WA}_{20-90 \%}$ foi eficiente em reduzir a doença, sem causar perdas de massa seca.

Palavras-chave: Solanum melongena; Verticillium dahliae; Patógeno de solo

Verticillium wilt is a vascular disease of numerous botanical species all over the world (16). Of the two Verticillium species that infect eggplants (Solanum melongena), V. dahliae Kleb. is considered the most important (13) and the only species in this genus that has been reported in Brazil (22). Verticillium penetrates the root of the host directly or through wounds, colonizing the xylem (24). Typical symptoms are branch wilting, frequently unilateral, leaf yellowing and leaf necrosis, in the form of an inverted "V", starting in the oldest leaves. Discoloration of the xylem vessels is also observed. Infected plants present atrophy, chlorosis and small leaves, which may culminate in the plant death. The fungus reaches the inside of the fruit and seeds (22).

Control of this disease is very difficult, given the wide range of hosts, survival structures and absence of resistant cultivars. Chemical control is ineffective since this is a vascular disease starting from a soil-borne inoculum $(18,26)$. Its management is based essentially on integrated measures focused on prevention, reduction in the initial inoculum and/or reduction in the multiplication rate (25). Solarization and soil fumigation are partially effective measures (17), as well as rotation with some Brassicacae (12), or the use of wild species of Solanum as rootstock for grafting $(8,18)$. Irrigation is one of the practices of greatest impact on the disease intensity, creating either favourable or adverse conditions for pathogens. It is of particular importance in the cultivation of vegetables, which normally need frequent and high-volume irrigation (19). The frequency, quantity and way in which water is applied to the plants interfere in the survival, dissemination, infection and colonization of pathogens and the severity of diseases $(6,7,19)$. Considering the relationship between irrigation and vascular pathogens, the development of the disease should be evaluated in both the infection and the post-colonization phases. In the infection phase, greater soil humidity favours the infection process 
and the pathogen multiplication, while in the post-colonization phase, xylem obstruction limits the water flow to the branches and leaves (24).

Unlike other soil pathogens, the interaction between water and Verticillium is complex, and the limited literature on this subject is somewhat controversial. There are reports of increased severity in cauliflower (Brassica oleraceae) and alfalfa (Medicago sativa) in moister soils $(27 ; 14)$ and of reduced severity in potato (Solanum tuberosum) with a larger irrigation depth (1). In eggplants, Bletsos et al. (3) did not confirm the effect of irrigation frequency on disease severity.

This study aimed to evaluate the relationship between water availability in the soil and verticillium wilt severity in eggplants, as well as to propose an irrigation management strategy that could prevent the pathogen and delay the disease progress.

\section{MATERIALS AND METHODS}

This study was carried out in the Biology Experimental Station at University of Brasilia, Federal District of Brazil, from June 2014 to January 2015. Four irrigation management strategies were established based on several limits of soil water availability and evaluated in eggplants cultivated in soil infested or not infested with $V$. dahliae.

Three strategies involved irrigating the plants when the soil water available to the plants (WA) was kept at $90 \%\left(\mathrm{WA}_{90 \%}\right), 55 \%\left(\mathrm{WA}_{55 \%}\right)$ and $20 \%\left(\mathrm{WA}_{20 \%}\right)$ during the whole crop cycle. In the fourth strategy, plants were irrigated according to their phenological stage: either when the available water was depleted to $20 \%$ during the vegetative stage, or when it increased to $90 \%$ during the production stage (WA ${ }_{20-90 \%}$ ). The management strategies $\mathrm{WA}_{90 \%}, \mathrm{WA}_{55 \%}$ and $\mathrm{WA}_{20 \%}$ express available water conditions considered high, moderate and low for the eggplant crop, respectively (20).

Experimental design was in randomized blocks, including eight treatments in $4 \times 2$ factorial arrangement, in which the first factor represented the water available in the soil and the second factor represented soil infestation, in three replicates. Experimental plots consisted of concrete tanks of $0.64 \mathrm{~m}^{2}(0.80 \mathrm{~m} \times 0.80 \mathrm{~m})$ internal area and $1.00 \mathrm{~m}$ height, which were filled with non-treated soil from the bottom up to $c .0 .40 \mathrm{~m}$ and with infested or noninfested autoclaved soil from $0.40 \mathrm{~m}$ up, as described below. The walls and the base of the tanks were $0.15 \mathrm{~m}$ thick, waterproof and pathogen-proof. Any excess water was drained by an opening on the low part of the tank side wall. Plots were protected against the rain by a semi-transparent cover, of $3.20 \mathrm{~m}$ width, fixed at $2.50 \mathrm{~m}$ above the ground.

The soil, classified as typical tropical savannah dystrophic redyellow oxisol, had clay texture (56\% clay; $37 \%$ silt; $7 \%$ sand). The soil water retention curve $(\theta, \%$ vol. $)$, in the tension interval $\left(\Psi_{\mathrm{m}}\right)$ from 5 to $1,500 \mathrm{kPa}$, was adjusted to the equation of van Genuchten (4): $\theta\left(\Psi_{\mathrm{m}}\right)$ $=22.6+17.3 /\left[1+\left(0.085 \Psi_{\mathrm{m}}\right)^{0.701}\right]^{0.549}$.

A combination of equal parts of two $V$. dahliae isolates (Vert. 15 and Vert. 120) was used for soil infestation; they were from the mycological collection of Embrapa Vegetable Crops and had been previously identified as highly aggressive in pathogenicity tests. The inoculum was initially cultivated in PDA + tetracycline $(500 \mathrm{ppm})$ at room temperature for seven days. Subsequently, four $1.0 \mathrm{~mm}$ mycelial discs from each isolate were placed in Erlenmeyer flasks with $100 \mathrm{~mL}$ potato dextrose broth. The culture medium was kept in a shaker for 15 days, at room temperature, for fungal growth. Spore suspensions were then filtered in double cheesecloth layers, and the inoculum concentration was adjusted to $2 \times 10 \square$ conidia per $\mathrm{mL}$, as described by Miranda et al.
(21). The suspension was used for inoculating vermiculite drenched in potato dextrose broth. Vermiculite was the chosen inoculum vehicle for presenting the most homogeneous distribution into the soil. Erlenmeyer flasks containing $200 \mathrm{~g}$ vermiculite enriched with potato dextrose broth, at the proportion of $2.25 \mathrm{~mL} \mathrm{~g}^{-1}$, were autoclaved at $121^{\circ} \mathrm{C}$ for $30 \mathrm{~min}$. The spore suspension ( $40 \mathrm{~mL} ; 2 \times 10 \square \mathrm{mL}^{-1}$ ) was then added to 500 $\mathrm{g}$ enriched vermiculite. The inoculated vermiculite was kept in plastic containers at room temperature for 20 days and manually shaken every 3 days for uniform fungal growth before soil infestation.

Plots of infested treatments received noninfested soil up to 0.40 $\mathrm{m}$ from the bottom, followed by a $0.15 \mathrm{~m}$ layer of soil infested with inoculum of $V$. dahliae, and again a $0.10 \mathrm{~m}$ layer of noninfested soil on the top. The layer at $0.10-0.25 \mathrm{~m}$ below the soil surface in the inoculated plots was mixed with $100 \mathrm{~g}$ vermiculite compost infested with Verticillium; homogenization of the autoclaved soil and vermiculite compost mixture was done in a cement mixer for $5 \mathrm{~min}$.

The eggplant hybrid Ciça ${ }^{\circledR}$ was used as the host plant. This material is developed and widely cultivated in the mid-western region of Brazil due to its resistance to Colletotrichum gloeosporioides and Phomopsis vexans. Four 30-day-old seedlings were transplanted per plot; they were spaced at $0.40 \times 0.40 \mathrm{~m}$, grown in new trays filled with commercial substrate and irrigated with water from a semi-artesian well.

To obtain a uniform stand and initial growth of plants, irrigation was the same throughout the first week for all plots. Watering was performed to keep $75-100 \%$ available water in the top layer of $0.10 \mathrm{~m}$ soil (20). From the second week onwards, watering was established based on the daily reading of tensiometric sensors. Two sensors per plot were installed at $40-50 \%$ of the effective root depth for the crop - initially at $0.05 \mathrm{~m}$ and then relocated to $0.25 \mathrm{~m}$ - at a distance of $0.10 \mathrm{~m}$ to 0.20 $\mathrm{m}$ from the plants, according to root growth (20).

For the use of sensors, the soil moisture retention equation was used to determine the limit-tensions associated with the available water content of $90 \%, 55 \%$ and $20 \%$, which were $8 \mathrm{kPa}, 45 \mathrm{kPa}$ and $275 \mathrm{kPa}$, respectively. Tensiometers were used for treatments $\mathrm{WA}_{90 \%}$ and $\mathrm{WA}_{55 \%}$, and Irrigas ${ }^{\circledR}$ was used for treatment $\mathrm{WA}_{20 \%}$. For treatment $\mathrm{WA}_{20-90 \%}$. Irrigas ${ }^{\circledR}$ was used during the vegetative stage $\left(2^{\text {nd }}\right.$ week after transplanting until the onset of fruiting), and tensiometers were used during the production stage (from the onset of fruiting until the end of the experiment). The use of two types of sensors, also adopted by Bilibio et al. (2) in studies of water tension in the soil with eggplants, was chosen because the tensiometer does not function at tensions above $80 \mathrm{kPa}(20)$.

The tension was read daily with the digital tensiometer, and watering was carried out when the mean of the readings from the sensors, installed in the plots of the same irrigation treatment, reached the limit $( \pm 10 \%)$ associated with the treatment. The Irrigas ${ }^{\circledR}$ sensors were set up with tubular sticks made of silicon carbide, $22 \mathrm{~mm}$ long, 220 $\mathrm{kPa}$ to $250 \mathrm{kPa}$ reference tension, produced by "Technicer Tecnologia Cerâmica". In this case, watering was carried out when at least three of the six Irrigas ${ }^{\circledR}$ installed in the plots of the same irrigation treatment indicated dry soil condition (20).

When the moment to irrigate was established, the water volume for the soil to go back to field capacity condition was supplied ( $5 \mathrm{kPa})$, based on the soil water retention curve (20). Irrigation was manual, and the water volume applied to each plot was measured with a Becker and a test-tube.

The cultural treatments were restricted to shoot elimination below the first bifurcation in the main stem of the plant, and insect pests, especially the whitefly (Bemisia tabaci), were controlled by application 
of a systemic insecticide of the neonicotinoid group. Air temperature and humidity sensors were installed at a height of $0.30 \mathrm{~m}$ on the side of one plot of each treatment, and soil temperature sensors were placed at a depth of $0.05 \mathrm{~m}$, at $0.10 \mathrm{~m}$ from the plant.

In each experimental plot, evaluations were performed to assess verticillium wilt severity, plant height, xylem darkening height caused by pathogen colonization, and dry mass of the aerial part (except fruits). Disease severity $\left(\mathrm{S}_{\mathrm{EV}} ; \%\right)$, evaluated at 200 days after transplanting (DAT), was determined by $\mathrm{S}_{\mathrm{EV}}=100 \Sigma[(\mathrm{f} . \mathrm{v}) /(\mathrm{n} . \mathrm{x})]$, considering: $\mathrm{f}=$ number of plants with the same grade; $\mathrm{v}=$ observed grade; $\mathrm{n}=$ total number of evaluated plants; and $\mathrm{x}=$ maximum grade on the grade scale used by Miranda et al. (21). The scale varied from 0 to 4 , where: $0=$ asymptomatic plants; 1 = plants without leaf symptoms, such as wilting and yellowing, but with vascular darkening; 2 = plants with yellowing and necrosis of leaves, reaching their lower third; 3 = plants showing wilting or under-development, yellowing and necrosis, reaching their upper third; and $4=$ dead or collapsed plants. Plant height, xylem darkening height and dry mass of the aerial part were evaluated at 202 DAT. After plants had been removed from the plots, their length was measured with a tape measure, and a longitudinal split was made in the main stem of each plant - from the collar to the base of the petiole. The xylem darkening height was measured with a ruler from the stem base upwards. Then, the plants - main stem, branch stalks and leaves - were dried in a forced ventilation oven, at $60{ }^{\circ} \mathrm{C}$, until reaching constant mass, to determine the dry mass of the aerial part.

Under these experimental conditions, plants were still in the flowering and fruiting stages at 202 DAT, and only three fruits could be collected per plant, on average, which was not enough for yield estimation. The increase in the cycle, which under normal field conditions would vary from 100 to 130 days (20), was probably the result of the semi-transparent cover fixed over the plants, which reduces the intensity of solar radiation and the speed of node branching (11). According to Marouelli et al. (20), the development cycle of the eggplant may extend to five months or longer than normal, depending on the plant health and the crop conditions. The experiment was concluded due to lengthening of the cycle, limitation of space to the sides and upwards for plant growth, and significant evidence of the effect of treatments on disease occurrence.

Data were subjected to analysis of variance, when applicable to factorial experimental designs, using " $F$ " test at 5\% significance. To compare the means of variables significantly affected by the water levels, Tukey's test was used at 5\% significance.

\section{RESULTS AND DISCUSSION}

The water volume applied to each plot was $292 \mathrm{~L}$ for treatment $\mathrm{WA}_{20 \%}, 532 \mathrm{~L}$ for $\mathrm{WA}_{55 \%}, 662 \mathrm{~L}$ for $\mathrm{WA}_{90 \%}$ and $435 \mathrm{~L}$ for $\mathrm{WA}_{20-90 \%}$. Treatment $\mathrm{WA}_{90 \%}$, which received the largest water volume, had the lowest irrigation frequency - a mean of 1.2 days; on the other hand, treatment $\mathrm{WA}_{20 \%}$ had a frequency of 9.8 days, more than twice that of $\mathrm{WA}_{55 \%}$ (mean of 3.8 days). For treatment $\mathrm{WA}_{20-90 \%}$, the irrigation frequency was 11.6 days during the vegetative stage and 1.6 days during the reproductive stage.

There were no differences in temperature (mean of $22.3^{\circ} \mathrm{C}$ ) or in relative air humidity (mean of 58.7\%) among treatments. Similarly, the soil temperature did not vary (mean of $20.7^{\circ} \mathrm{C}$ ), indicating it had no differential effect among treatments.

A significant reduction in verticillium wilt severity was observed for treatment $\mathrm{WA}_{20-90 \%}$ (disease severity index $=21.8 \%$; Figure 1). The other treatments did not differ statistically among them (50.0-59.4\%). The lowest soil water availability during the vegetative stage of eggplants probably delayed the root infection process in treatment $\mathrm{WA}_{20-90 \%}$. Johnson and Dung (15) recommended that management of Verticillium in other Solanaceae host plants (potato, S. tuberosum) should be focused on the combination of practices to reduce the initial inoculum, restrict vascular infection and subsequently restrict xylem colonization. In fact, even under ideal conditions, it is known that only a small fraction of the soil inoculum that manages to penetrate the host ends up causing systemic infection (16). Thus, the lower initial water availability in the soil for treatment $\mathrm{WA}_{20-90 \%}$ may have further reduced the percentage of root infections that reached the vascular tissue at the beginning of the crop cycle. Then, for the plants only partially colonized by the pathogen, the supply of a greater amount of water available in the soil, from the production stage onwards, compensated for the partial obstruction of the xylem, making it easier to transport water from the soil to the aerial part (19). This effect was not verified for treatment $\mathrm{WA}_{20 \%}$, in which the water deficit was maintained throughout the whole crop cycle. Thus, the low water availability in the soil probably delayed the infectious process during the vegetative stage and did not favour the pathogen colonization process during the production stage for treatment $\mathrm{WA}_{20 \%}$; however, the hydric deficit during the production stage damaged the host, reducing photosynthesis and affecting the synthesis of metabolites and enzymes that are important in the expression of plant resistance, as reported by Boyer (5).

In an analogous study with potato crop, Cappaert et al. (9) verified that excess soil humidity at the tubercle formation stage increased the incidence of $V$. dahliae wilt by $22 \%$, compared with management that produced water deficit during the pre-tuberization stage, independently of the water quantity applied from the tuberization stage onwards. Therefore, irrigation at moderate deficits during the vegetative stage is recommended, a management strategy that reduces damage by soilborne diseases and induces the roots to reach deeper depths, without significantly reducing yield $(19,20)$. In addition, Bilibio et al. (2) stated that the eggplant crop is tolerant to water scarcity in the soil during the vegetative stage, further recommending this water management strategy.

The mean plant height $(1.41 \mathrm{~m})$ was not significantly affected by soil infestation or soil water availability $(\mathrm{p}>0.05)$. On the other hand, the height to which the xylem was colonized by the pathogen in the infested treatments was greatest for treatment $\mathrm{WA}_{90 \%}(0.73 \mathrm{~m})$, while xylem lesions were much smaller for treatments $\mathrm{WA}_{20-90 \%}(0.38 \mathrm{~m})$ and $\mathrm{WA}_{20 \%}(0.44 \mathrm{~m})$. The mean lesion length for treatment $\mathrm{WA}_{55 \%}(0.47$ $\mathrm{m})$ did not differ significantly from the other treatments conducted in inoculated soil (Figure 1). The significant difference in lesion lengths between treatments $\mathrm{WA}_{90 \%}$ and $\mathrm{WA}_{20 \%}$ corroborates the studies of Cook and Papendick (10) and Schnathorst (24), in which lower soil water availability was reported to be unfavourable for pathogen colonization of plant tissues. No contamination by $V$. dahliae was observed for the noninfested treatments, confirmed by the absence of external and internal symptoms. Consequently, disease severity and vascular discoloration were null for these treatments.

Effects of soil infestation and soil water availability on the dry mass of the aerial part of plants were significant, but there was no significant interaction between these factors $(\mathrm{P}>0.05$; Table 1$)$. Dry mass was significantly reduced when the water deficit increased, irrespective of whether plants were cultivated in infested or noninfested soil. The largest amount of dry mass was observed for treatment $\mathrm{WA}_{90 \%}$ (mean of 

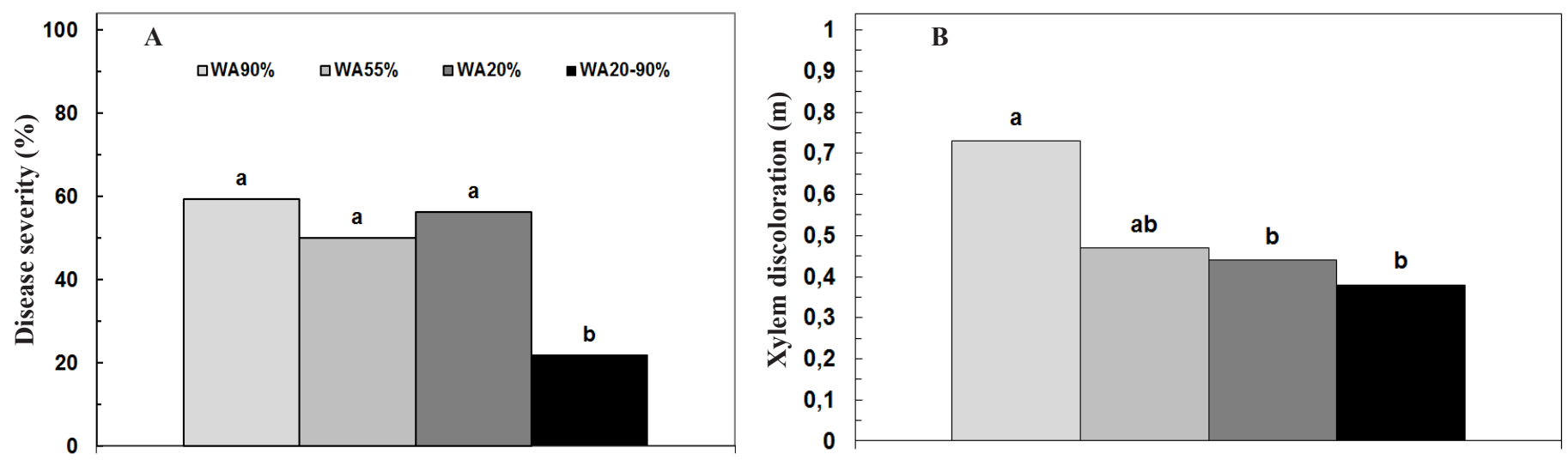

Figure 1. Severity of verticillium wilt (A) and length of xylem discoloration (B) caused by colonization by Verticillium dahliae in eggplants cultivated in infested soil at several water levels. Means followed by the same letters in the rows do not differ according to Tukey's test at $5 \%$ probability.

Table 1. Dry mass (g) of the aerial part of eggplants (except fruits) in soil infested and noninfested with Verticillium dahliae at several soil water levels ${ }^{(1)}$.

\begin{tabular}{|c|c|c|c|c|c|}
\hline \multirow{2}{*}{ Soil infestation } & \multicolumn{4}{|c|}{ Water available in the soil } & \multirow{2}{*}{ Mean } \\
\hline & $90 \%$ & $55 \%$ & $20 \%$ & $20-90 \% 0^{(2)}$ & \\
\hline Noninfested soil & 925.7 & 666.0 & 625.2 & 693.3 & $727.6 \mathrm{~A}$ \\
\hline Infested soil & 729.2 & 580.6 & 526.2 & 728.7 & $641.2 \mathrm{~B}$ \\
\hline Mean & $859.0 \mathrm{a}$ & $631.8 \mathrm{~b}$ & $585.6 \mathrm{~b}$ & $707.5 \mathrm{ab}$ & C.V. $=12 \%$ \\
\hline
\end{tabular}

${ }^{(1)}$ Means followed by the same lowercase letters in the rows or uppercase letters in the columns do not differ according to Tukey's test at $5 \%$ probability (non-significant interaction between factors). ${ }^{(2)}$ Water availability (WA) of $20 \%$ during the vegetative stage and $90 \%$ during the production stage.

$859.0 \mathrm{~g}$ ), and significant differences were not found between treatments $\mathrm{WA}_{55 \%}$ (mean of $585.5 \mathrm{~g}$ ) and $\mathrm{WA}_{20 \%}$ (mean of $631.8 \mathrm{~g}$ ). The dry mass of eggplants initially irrigated with a deficit and without a deficit at the production stage $\left(\mathrm{WA}_{20-90 \%}\right.$ ) reached $707.5 \mathrm{~g}$, not different from that of the most irrigated treatment $\left(\mathrm{WA}_{90 \%)}\right.$. On the other hand, plants cultivated in infested soil presented a mean reduction of $12 \%$ in the dry mass in relation to plants cultivated in healthy soil (Table 1), indicating that verticillium wilt hampered the host vegetative development. Similarly, Sanogo et al. (23) found that the dry mass of the aerial part of sweet pepper plants (Capsicum annuum L.) was not affected by the interaction between the factors inoculation with $V$. dahliae and soil inundation, but only by the isolated effect of each factor.

Briefly, (i) the dry mass of plants cultivated in soil infested with $V$. dahliae was significantly reduced, compared with plants in noninfested soil; (ii) the irrigation management strategy $\mathrm{WA}_{20-90 \%}$ significantly reduced the severity of verticillium wilt and the length of xylem colonization by $V$. dahliae; (iii) the dry mass of eggplants was progressively reduced with the reduction in soil water availability from $90 \%$ to $20 \%$ throughout the crop cycle, but not when the plants were irrigated under the management strategy $\mathrm{WA}_{20-90 \%}$, and (iv) the management strategy $\mathrm{WA}_{20-90 \%}$ proved to be a feasible way to reduce verticillium wilt in eggplants, with no loss of dry mass of the aerial part.

In conclusion, despite the complexity of the interaction between soil water content and pathogen inoculum in the soil, this study indicates that the reduction in water availability during the crop's vegetative stage, followed by greater availability in the reproductive stage, is an effective strategy for reducing verticillium wilt in eggplants, without harming the plant development. Therefore, this strategy should be taken into account in an integrated disease management strategy for verticillium wilt, along with preventive measures such as use of healthy seeds and seedlings, reduction in the initial inoculum by solarisation, fumigation and rotation with nonhosts, and use of resistant rootstock for grafting.

\section{ACKNOWLEDGEMENTS}

The first author was a recipient of master's scholarship from the Brazilian National Research Council (CNPq). A.C. Café-Filho is a Brazilian National Research Council Fellow (CNPq grant no. 301758/2017-4).

\section{REFERENCES}

1. ARBOGAST, M.; POWELSON, M. L.; CAPPAERT, M. R.; WARTRUD, L. S. Response of six potato cultivars to amount of applied water and Verticillium dahliae. Phytopathology, Saint Paul, v. 89, n. 9, p. 782-788, 1999.

2. BILIBIO, C.; CARVALHO, J. A.; MARTINS, M.; REZENDE, F. C.; FREITAS, E. A.; GOMES, L. A. A. Desenvolvimento vegetativo e produtivo da berinjela submetida a diferentes tensões de água no solo. Revista Brasileira de Engenharia Agrícola e Ambiental, Campina Grande, v. 14, n. 7, p. 730-735, 2010.

3. BLETSOS, F. A.; THANASSOULOPOULOS, C. C.; ROUPAKIAS, D. G. Water stress and verticillium wilt severity on eggplant (Solanum melongena). Journal of Phytopathology, Göttingen, v. 147, p. 243-248, 1999.

4. BORGES JÚNIOR, J. C. F.; FERREIRA, P. A.; HEDDEN-DUNKHORST, B.; ANDRADE, C. L. T. Modelo computacional para suporte à decisão em áreas irrigadas: desenvolvimento e análise de sensibilidade. Revista Brasileira de Engenharia Agrícola e Ambiental, Campina Grande, v. 12, n. 1, p. 3-11, 2008.

5. BOYER, J. S. Biochemical and biophysical aspects of water deficits and the predisposition to disease. Annual Review of Phytopathology, Palo Alto, v. 33, p. 251-274, 1995.

6. CABRAL, R. N.; MAROUELLI, W. A.; LAGE, D. A. C.; CAFÉ FILHO, A. 
C. Septoria leaf spot in organic tomatoes under diverse irrigation systems and water management strategies. Horticultura Brasileira, Brasília, v. 31, n. 3, p. 392-400, 2013.

7. COELHO, M. V. S.; PALMA, F. R.; CAFÉ FILHO, A. C. Management of strawberry anthracnose by choice of irrigation system, mulching material and host resistance. International Journal of Pest Management, Oxford, v. 54, p. 347-354, 2008.

8. ÇÜRÜK, S.; DASGAN, H. Y.; MANSUROGLU, S.; KURT, S.; MAZMANOGLU, M.; ANTAK, Ö.; TARLA, G. Grafted eggplant yield, quality and growth in infested soil with Verticillium dahliae and Meloidogyne incognita. Pesquisa Agropecuária Brasileira, Brasília, v. 44, n. 12, p. 1673-1681, 2009.

9. CAPPAERT, M. R.; POWELSON, M. L.; CHRISTENSEN, N. W.; STEVENSON, W. R.; ROUSE, D. I. Assessment of irrigation as a method of managing potato early dying. Phytopathology, Saint Paul, v. 84, n. 8, p. 792-800, 1994.

10. COOK, R. J.; PAPENDICK, R. I. Influence of water potential of soils and plants on root disease. Annual Review of Phytopathology, Palo Alto, v. 10, p. 349-374, 1972.

11. HELDWEIN, A. B.; STRECK, N. A.; STURZA, V. S.; LOOSE, L. H.; ZANON, A. J.; TOEBE, M.; SOUZA, A. T.; PETERS, M. B.; KARLEC, F. Plastocrono e rendimento de feijão-de-vagem cultivado sob ambiente protegido e no ambiente externo em semeadura tardia no outono. Ciência Rural, Santa Maria, v. 40, n. 4, p. 768-773, 2010.

12. IKEDA, K.; BANNO, S.; FURUSAWA, A.; SHIBATA, S.; NAKAHO, K.; FUJIMURA, M. Crop rotation with broccoli suppresses Verticillium wilt of eggplant. Journal of General Plant Pathology, Okayama, v. 81, n. 1, p.77-82, 2015.

13. INDERBITZIN, P.; SUBBARAO, K. V. Verticillium systematics and evolution: How confusion impedes Verticillium wilt management and how to resolve it. Phytopathology, Saint Paul, v. 104, n. 6, p. 564-574, 2014.

14. JEFFERSON, P. G.; GOSSEN, B. D. Irrigation increases verticillium wilt incidence in a susceptible alfalfa cultivar. Plant Disease, Saint Paul, v. 86, n. 6, p. 588-592, 2002.

15. JOHNSON, D. A.; DUNG, J. K. S. Verticillium wilt of potato - the pathogen, disease and management. Canadian Journal of Plant Pathology, Burnaby, v. 32, n. 1, p. 58-67, 2010.

16. KLOSTERMAN, S. J.; ATALLAH, Z. K.; VALLAD, G. E.; SUBBARAO, K. V. Diversity, pathogenicity, and management of Verticillium species. Annual Review of Phytopathology, Palo Alto, v. 47, p. 39-62, 2009.
17. LARKIN, R. P; HONEYCUTT, W.; OLANYA, O. M. Management of verticillium wilt of potato with disease-suppressive green manures and as affected by previous cropping history. Plant Disease, Saint Paul, v. 95, n. 5, p. 568-576, 2011.

18. LIU, J.; ZHENG, Z.; ZHOU, X.; FENG, C.; ZHUANG, Y. Improving the resistance of eggplant (Solanum melongena) to Verticillium wilt using wild species Solanum linnaeanum. Euphytica, New York, v. 201, p. 463-469, 2015.

19. LOPES, C. A.; MAROUELli, W. A.; CAFÉ FILHO, A. C. Associação da irrigação com doenças de hortaliças. Revisão Anual de Patologia de Plantas, Brasília, v. 14, p. 151-179, 2006.

20. MAROUELli, W. A.; BRAGA, M. B.; SILVA, H. R., COSTA, C. S. Irrigação na cultura da berinjela. Brasília: Embrapa Hortaliças, 2014. 24 p. (Circular Técnica 135).

21. MIRANDA, B. E. C.; BOITEUX, L. S.; CRUZ, E. M.; REIS, A. Fontes de resistência em acessos de Solanum (secção Lycopersicon) a Verticillium dahliae raças 1 e 2 . Horticultura Brasileira, Brasília, v. 28, n. 4, p. 458 465, 2010.

22. REIS, A.; BOITEUX, L. S.; LOPES, C. A. Doenças da berinjela no Brasil. Brasília: Embrapa Hortaliças, 2011. 8 p. (Circular Técnica 97).

23. SANOGO, S.; EL-SEBAI, O. I.; SANDERSON, R. Severity of verticillium wilt, plant growth, and spectral reflectance indices of chili peper under periodic flooding and no-flooding conditions. HortScience, Alexandria, v. 43, n. 2, p. 414-419, 2008.

24. SCHNATHORST, W. C. Life cycle and epidemiology. In: MACE, M. E.; BELL, A. A.; BECKMAN, C. H. Fungal wilt diseases of plants. New York: Academic Press. 1981. p. 81-111.

25. SHORT, D. P. G.; SANDOYA, G.; VALLAD, G. E.; KOIKE, S. T.; XIAO, C.; WU, B.; GURUNG, S.; HAYES, R. J.; SUBBARAO, K. V. Dynamics of Verticillium species microsclerotia in field soils in response to fumigation, cropping patterns, and flooding. Phytopathology, Saint Paul, v. 105, n. 5, p. 635-645, 2015.

26. VILLENEUVE, F.; LATOUR, F.; THÉRY, T.; STEINBERG, C.; EDEL-HERMANN, V.; PITRAT, M.; DAUNAY, M. C. The control of soil borne vascular diseases: limits of genetic resistance of cultivars and rootstocks for controlling Fusarium oxysporum f. sp. melonis (melon) and Verticillium sp. (eggplant). Acta Horticulturae, Leuven, v. 1044, n. 1, p. 57-65, 2014.

27. XIAO, C. L.; SUBBARAO, K. V. Effects of irrigation and Verticillium dahliae on cauliflower root and shoot growth dynamics. Phytopathology, Saint Paul, v. 90, n. 9, p. 995-1004, 2000. 